Jurnal Syarikah P-ISSN 2442-4420 e-ISSN 2528-6935 Volume 2 Nomor 2, Desember 2016|311

\title{
ANALISIS PRAKTIK DAN PENGELOLAAN WAKAF UANG MENURUT UNDANG-UNDANG NOMOR 41 TAHUN 2004 TENTANG WAKAF
}

\section{ANALYSIS OF PRACTICE AND CASH WAQF MANAGEMENT BASE ON WAQF CONSITUTION NO. 41 YEAR 2004}

\author{
M.Shofi ${ }^{1}$ \\ 1Program Studi Hukum Ekonomi Syariah Sekolah Tinggi Ilmu Ekonomi Islam Tazkia, Jl. Ir. \\ H. Djuanda No.78 Sentul City, Bogor 16810.
}

\begin{abstract}
The purpose of this study is to analyze the management of waqf money at TWI and its compliance with the Act No. 41 of 2004 on waqf. The research method used descriptive qualitative method. The results of this study demonstrate the practice of waqf money in Tabung Wakaf Indonesia. There are two ways practice of waqf money in TWI first by a cash deposit or transfer in the bank already has a decree of the Minister in this case Bank Syariah Mandiri and BNI Syariah and the second by coming directly to the office Dompet Dhuafa either center or branches in every city. Approach to the management of waqf at TWI using three approaches productive, non-productive and integrated management. Most of endowment management practices at TWI in accordance with the act, except for percentages between LKS PWU and beyond LKS PWU.
\end{abstract}

Keywords: Waqf, TWI

\begin{abstract}
ABSTRAK
Tujuan penelitian ini adalah untuk menganalisis pengelolaan wakaf uang di TWI dan kesesuaiannya dengan Undang-Undang No. 41 Tahun 2004 tentang wakaf. Metode penelitian menggunakan metode deskriptif kualitatif. Hasil penelitian ini menunjukkan praktik wakaf uang yang ada di Tabung Wakaf Indonesia ada dua cara pertama melalui setor tunai atau transfer di bank yang sudah memiliki SK dari Menteri dalam hal ini Bank Syariah Mandiri dan BNI Syariah dan kedua dengan datang langsung kekantor Dompet Dhuafa baik pusat atau cabang-cabang disetiap kota. Pendekatan pengelolaan wakaf di TWI menggunakan tiga pendekatan produktif, non produktif dan pengelolaan terpadu. Sebagian besar praktik pengelolaan wakaf di TWI sesuai dengan Undang-Undang, kecuali untuk persentase antara LKS PWU dan diluar LKS PWU.
\end{abstract}

Kata kunci: Wakaf, TWI.

Shofi, Muhammad. 2016. Analisis Praktik dan Manajemen Pengelolaan Wakaf Uang Menurut Undang-Undang No. 41 Tahun 2004 Tentang Wakaf. Jurnal Syarikah 2 (2): 311-327. 


\section{PENDAHULUAN}

Wakaf merupakan salah satu bangunan penting ekonomi Islam, bersama dengan zakat, infak dan sedekah yang dikenal dengan ZISWAF. Wakaf menjadi instrumen penting dalam pembangunan ekonomi berbasis Syariah Islamiyah, terutama yang berkaitan dengan sosial dan ekonomi seperti pemberdayaan ekonomi umat, pengentasan kemiskinan, dan peningkatan kualitas sumber daya manusia. Lebih dalam lagi untuk mewujudkan pemerataan pendapatan dan kekayaan dalam masyarakat. Keempat instrumen ini merupakan ajaran yang bersumber dari Allah swt sebagaimana dalam firmannya:

"Kamu sekali-kali tidak sampai kepada kebajikan yang sempurna, sebelum kamu menafkahkan sebagian harta yang kamu cintai. Dan apa saja yang kamu nafkahkan maka sesungguhnya Allah mengetahuinya." (QS Al Imran: 92)

Wakaf sesungguhnya memiliki peranan yang cukup besar dalam mewujudkan tata sosial yang berkeadilan, meningkatkan kesejahteraan umat pada skala mikro dan menciptakan kestabilan ekonomi negara apabila dikelola dengan produktif dan profesional.

Lahirnya Undang-Undang Nomor 41 Tahun 2004 tentang wakaf ini memberikan jalan bagi perkembangan wakaf di Indonesia, terutama wakaf uang dimana dalam Undang-Undang wakaf tersebut, wakaf uang menjadi salah satu jenis wakaf yang mendapat perhatian khusus, ini dikarenakan wakaf uang adalah inovasi baru dalam perwakafan Indonesia yang memiliki potensi yang besar untuk dikembangkan guna meningkatkan peran wakaf dalam bidang ekonomi.

Menurut perhitungan yang dilakukan oleh Musatafa Edwin Nasution potensi wakaf uang di Indonesia sangat besar yaitu tiga triliyun pertahun. Besarnya potensi wakaf di Indonesia tentu saja memerlukan manajemen pengelolaan yang baik dan profesional yang mampu untuk menjadikan aset wakaf yang ada menjadi produktif. Selain memiliki potensi besar, wakaf uang juga sangat rawan terhadap penyalahgunaan karena itu perlu adanya Undang-Undang yang mengatur manajemen wakaf uang dari mulai praktik dan pengelolaannya.

Dalam Undang-Undang No. 41 Tahun 2004 disebutkan bahwa wakaf uang merupakan bagian dari harta benda wakaf bergerak, yaitu harta benda yang tidak bisa habis karena dikonsumsi, meliputi: uang, logam mulia, surat berharga, kendaraan, hak atas kekayaan intelektual, hak sewa, dan benda bergerak lain sesuai dengan ketentuan syariah dan peraturan perundang-undangan yang berlaku. Juga terdapat pada pasal 28,29,30 dan 31. Pada pasal 28 disebutkan: "Wakif dapat mewakafkan benda bergerak berupa uang melalui lembaga keuangan syariah yang ditunjuk oleh Menteri".

Pengelolaan harta benda wakaf berupa uang ini memiliki acuan yang terdapat dalam Undang-Undang wakaf, baik Undang-Undang No. 41 tahun 2004 tentang wakaf dan Peraturan Pemerintah No. 42 tahun 2006 tentang pelaksanaan Undang-Undang Nomor 41 tahun 2004 tentang wakaf, Peraturan Menteri Agama No 4 tahun 2009 tentang administrasi wakaf uang, Keputusan Menteri Agama No. 92-96 Tentang Penetapan lima LKS menjadi LKS PWU, Keputusan Direktur 
Jenderal Bimbingan Masyarakat Islam No. DJ.II/420 Tahun 2009 tentang Model, Bentuk, dan spesifikasi formulir wakaf uang, Peraturan Badan Wakaf Indonesia No. 1 Tahun 2009 tentang Pedoman Pengelolaan dan Pengembangan Harta benda wakaf bergerak berupa uang.

\section{MATERI DAN METODE}

\section{Pendekatan dan Jenis Penelitian}

Penelitian ini merupakan tipe penelitian normatif empiris hal ini karena dalam penelitian ini mengkaji tentang perpaduan antara undang-undang dengan praktik yang berlaku dilapangan.

Dalam dunia pendidikan pendekatan penelitian yang terkenal terbagi menjadi dua penelitian yaitu kualitatif dan kuantitatif. Dalam penulisan skripsi ini peneliti menggunakan pendekatan kualitatif deskriptif analitis dimana dalam penelitian ini lebih menekankan pada makna dan proses daripada hasil suatu aktivitas. Menurut Sugiyono (2008) bahwa penelitian Kualitatif deskriptif adalah metodologi penelitian berdasarkan pada filsafat post positivisme yang biasa digunakan Untuk meneliti pada kondisi objektif yang alamiah dimana peneliti berperan sebagai instrumen kunci. Sementara menurut Bagman dan Taylor mendefinisikan metodologi kualitatif sebagai prosedur penelitian yang menghasilkan data deskripsi berupa kata-kata tertulis atau lisan dari orang-orang dan perilaku yang diamati.

Penelitian kualitatif deskriptif lebih banyak dipengaruhi oleh pandanganpandangan deduktif kuantitatif. Bahkan dalam sejarah penelitian kualitatif, pendekatan kualitatif-deskriptif ini sendiri tidak sepenuhnya mengakar pada penelitian kualitatif, namun hanya kebiasaan dan pengaruh antara pandangan kuantitatif kualitatif akhirnya melahirkan tipe penelitian kualitatif deskriptif tersebut, sehingga tipe penelitian kualitatif deskriptif lebih tepat disebut sebagai quasi-kualitatif. Lebih lanjut lagi dijelaskan bahwa peneliti-peneliti kualitatif deskriptif berupaya keras agar pembahasan mereka lebih cenderung kualitatif dari pada kuantitatif, dengan mendekati makna dan ketajaman analisis logis dan juga dengan menjauhi statistik sejauh-jauhnya. Maka kualitatif deskriptif dan diterima sebagai salah satu tipe penelitian kualitatif.

\section{Lokasi Penelitian}

Penelitian ini dilakukan di kantor Tabung Wakaf Indonesia yang bertempat di Perkantoran Ciputat Indah Permai Blok C25 Jl. Ir H Juanda no 50. Dipilihnya Tabung Wakaf Indonesia ini karena beberapa pertimbangan diantaranya:

1) Tabungan Wakaf Indonesia Dompet Dhuafa merupakan salah satu nazhir wakaf yang memiliki kinerja yang bagus dalam pengelolaan harta wakaf di Indonesia.

2) Tabungan Wakaf Indonesia memiliki transparansi publik yang bagus dalam penerimaan dan pengelolaan harta wakaf.

\section{Jenis dan Sumber Data}

\section{Data Primer}

Data primer merupakan sebuah informasi dan data yang diperoleh penulis secara langsung dari tempat penelitian atau objek penelitian. Data yang diperoleh merupakan hasil dari wawancara dengan pihak Tabung Wakaf Indonesia yang diamanahi memberikan informasi, dan dokumen tertulis atau yang terdapat dalam website lembaga seperti laporan kegiatan, program dan agenda lembaga tempat penelitian. 


\section{Data Sekunder}

Data sekunder merupakan data-data yang sudah tersedia dan dapat diperoleh oleh penulis dengan cara membaca, melihat atau mendengarkannya. Dalam penelitian ini, penulis akan memperoleh data berupa jurnal, buku dan hasil penelitian terdahulu yang berkaitan dengan penelitian.

\section{Teknik Pengumpulan Data}

Metode Pengumpulan data yang digunakan dalam penelitian ini sebagaimana umumnya penelitian kualitatif adalah metode wawancara mendalam, observasi, dan dokumentasi.

\section{Wawancara}

Wawancara adalah proses memperoleh keterangan untuk tujuan penelitian dengan cara tanya jawab sambil bertatap muka antara pewawancara dengan informan atau orang yang diwawancarai, dengan atau tanpa menggunakan pedoman wawancara. Wawancara sebagai upaya mendekatkan informasi dengan cara bertanya langsung kepada informan. Adapun wawancara yang dilakukan adalah wawancara tidak berstruktur, dimana didalam metode ini memungkinkan pertanyaan berlangsung luwes, arah pertanyaan lebih terbuka, tetap fokus, sehingga diperoleh informasi yang kaya dan pembicaraan tidak kaku. Wawancara yang dilakukan disini adalah dengan pihak pengurus atau staf Tabung Wakaf Indonesia Dompet Dhuafa.

\section{Observasi}

Observasi

$$
\text { adalah }
$$

kemampuan seseorang untuk menggunakan pengamatannya melalui hasil kerja panca indra mata serta dibantu panca indra lainnya. Maksud dari metode observasi adalah metode pengumpulan data yang digunakan untuk menghimpun data penelitian melalui pengamatan dan pengindraan. Metode observasi ini dilakukan secara teliti dan sistematis untuk mendapatkan hasil yang bisa diandalkan. Observasi disini dengan cara terjun langsung ketempat penelitian yaitu Tabung Wakaf Indonesia Dompet Dhuafa.

\section{Dokumentasi}

Dokumentasi adalah proses melihat kembali sumber-sumber data dari dokumen yang ada dan dapat digunakan untuk memperluas data-data yang telah ditemukan. Adapun sumber data dokumen diperoleh dari lapangan berupa buku, arsip, majalah dan penelitian terdahulu serta dokumen perusahaan atau dokumen resmi yang berhubungan dengan fokus penelitian.

\section{Metode Analisis Data}

Data yang diperoleh baik dari lapangan maupun studi pustaka merupakan data kualitatif yang akan dikembangkan menjadi metode deskripsi yaitu metode yang menggambarkan secara jelas mengenai topik penelitian yang diteliti dan mengambil kesimpulan tentang hasil penelitian.

\section{HASIL DAN PEMBAHASAN}

\section{Sekilas Tentang Tabung Wakaf Indonesia}

Tabung Wakaf Indonesia (TWI) merupakan badan unit otonom dengan landasan badan hukum Dompet Dhuafa Republika, berdiri pada tanggal 14 juli 2005. Tabung Wakaf Indonesia (TWI) adalah lembaga yang berkhidmat meningkatkan kesejahteraan masyarakat dengan menggalang dan mengelola sumberdaya wakaf secara produktif, profesional dan amanah.

TWI didirikan oleh Dompet Dhuafa sebagai sebuah komitmen dalam mengembangkan sumberdaya wakaf agar 
mampu produktif dan mendukung pengembangan program-program sosial dan pemberdayaan ekonomi yang selama ini telah terlaksana berkat pengelolaan sumberdaya zakat, infak dan sedekah secara amanah dan profesional.

Tabung Wakaf Indonesia Dhompet Dhuafa (TWI-DD) terdaftar sebagai nazhir wakaf di Badan Wakaf Indonesia pada 16 Juni 2011 dengan nomer pendaftaran 36.74.3.1.1111, dan terdaftar sebagai nazhir wakaf uang pada hari kamis tanggal 5 Februari 2015 yang disahkan oleh BWI. Dalam menjalankan kerjanya TWI memiliki beberapa produk wakaf, jenisjenis produk wakaf di TWI terdiri dari wakaf tunai, wakaf tanah dan Bangunan (properti), wakaf bisnis dan usaha, serta wakaf saham dan surat berharga dan pada tahun ini TWI memiliki produk wakaf hadiah terbaik bunda:

1. Wakaf tunai dari seorang individu, bersama dengan individu atau donatur lainnya, akan digabungkan hingga terkumpul cukup modal untuk diinvestasikan pada sebuah aset produktif yang ditetapkan oleh pengelola (TWI). Surplus atas aset produktif tersebut kemudian akan didayagunakan untuk programprogram sosial sesuai peruntukan manfaatnya (pendidikan, kesehatan, atau pemberdayaan). Wakaf tunai meliputi: 1. uang 2. emas dan perak batangan 3. dinar dan dirham 4 . perhiasan emas dan perak.

2. Wakaf tanah dan bangunan (properti), tanah dan bangunan yang akan diwakafkan tentu harus dimiliki secara sah (bebas sengketa hukum), penuh (bebas utang), dan telah memperoleh persetujuan dari ahli waris (jika ada). Jika dipandang berpotensi untuk diproduktifkan, maka aset akan dikembangkan dengan modal pengelola (yang bersumber dari wakaf via tunai) ataupun dikerjasamakan dengan pihak ketiga dengan prinsip saling menguntungkan. Namun, jika dirasakan potensinya lemah atau bahkan berat, saat dipandang perlu, pengelola meminta izin agar tanah/bangunan tersebut dapat dijual dan digabungkan dengan aset yang lain (ruislag) agar memberikan manfaat yang lebih besar. Nilai wakaf yang dicatat selanjutnya adalah sebesar hasil nilai ruislag yang diperoleh. Wakaf tanah dan bangunan diantaranya: 1. tanah 2. rumah 3 . apartemen 4. kios/ruko 5. bangunan komersial (perkantoran, hotel, mal, pasar, gudang, pabrik) 6. bangunan sarana publik (sekolah, rumah sakit, klinik, dan lain-lain).

3. Wakaf bisnis dan usaha, selain wakaf tunai dan wakaf tanah dan bangunan, wakaf juga bisa berupa bisnis dan usaha. Seseorang yang memiliki beragam jenis usaha, dan menginginkan salah satu usahanya dijadikan "mesin profit" yang dapat memberikan maslahat luas kepada umat dapat berwakaf bisnis dan usaha. Dalam konteks wakaf bisnis dan usaha ini, seluruh aset, baik aset tetap maupun aset manajemen, dialihkan kepada TWI. Dengan demikian, TWI menjadi pemilik baru yang selanjutnya bertanggung jawab atas pengelolaan bisnis dan usaha.

Bentuk-bentuk usaha yang dapat diwakafkan antara lain:

1. Usaha layanan publik: klinik, rumah sakit, sekolah, universitas, sarana olahraga. 
2. Usaha komersial: minimarket, restoran, waralaba, pabrik, hotel.

4 Wakaf saham dan surat berharga, wakaf juga bisa berupa saham dan surat berharga. Surat-surat berharga yang dapat diwakafkan melalui TWI antara lain: 1. saham perusahaan syariah terbuka (terdaftar di Bursa Efek) 2. goodwill saham perusahaan syariah tertutup 3. sukuk (obligasi) syariah 4. sukuk (obligasi) retail syariah 5. deposito syariah 6 . reksadana syariah 7. wasiat wakaf dalam polis asuransi 8. wasiat wakaf dalam surat wasiat.

5. Produk wakaf yang terbaru dari TWI adalah wakaf hadiah terbaik bunda, program ini mengajak kita untuk berwakaf atas diri sendiri juga kita dapat berwakaf atas nama orang tua. Wakaf melalui uang akan dipergunakan untuk program pendidikan, kesehatan, dan pengembangan ekonomi.

Dari berbagai produk wakaf yang ada TWI memiliki beberapa program untuk peruntukan penyaluran manfaat wakaf yaitu untuk kepentingan bidang pendidikan, kesehatan dan pemberdayaan ekonomi.

\section{Praktik Wakaf Uang dalam Undang- Undang.}

Peraturan wakaf di Indonesia tertuang dalam Undang-Undang Nomor 41 Tahun 2004 tentang wakaf dan Peraturan Pemerintah Nomor 42 Tahun 2006 tentang Pelaksanaan UndangUndang Nomor 41 Tahun 2004 tentang wakaf. Disebutkan dalam Undang-Undang tersebut "wakaf adalah perbuatan hukum wakif untuk memisahkan dan/atau menyerahkan sebagian harta benda miliknya untuk dimanfaatkan selamanya atau untuk jangka waktu tertentu sesuai dengan kepentingannya guna keperluan ibadah dan/atau kesejahteraan umum menurut syariah".

Mekanisme wakaf uang ada dalam pasal 16 ayat 1-3 tentang pembagian harta benda wakaf, disebutkan bahwa harta benda wakaf ada dua macam benda bergerak dan benda tidak bergerak. Uang termasuk dari jenis harta benda wakaf yang bergerak, maksud harta benda bergerak adalah harta benda yang tidak bisa habis karena dikonsumsi, meliputi: uang, logam mulia, surat berharga, kendaraan, hak atas kekayaan intelektual, hak sewa, dan benda bergerak lain sesuai dengan ketentuan syariah dan peraturan perundangundangan yang berlaku.

Khusus untuk benda bergerak berupa uang diatur pada bagian kesepuluh Undang-Undang wakaf, pada pasal 28, 29, 30 dan 31. Tentang wakaf benda bergerak berupa uang.

1. Pasal 28: Wakif dapat mewakafkan benda bergerak berupa uang melalui lembaga keuangan syariah yang ditunjuk oleh Menteri

2 Pasal 29: 1). wakaf benda bergerak berupa uang sebagaimana dimaksud dalam Pasal 28 dilaksanakan oleh wakif dengan pernyataan kehendak wakif yang dilakukan secara tertulis. 2). wakaf benda bergerak berupa uang sebagaimana dimaksud pada ayat (1) diterbitkan dalam bentuk sertifikat wakaf uang. 3). sertifikat wakaf uang sebagaimana dimaksud pada ayat (2) diterbitkan dan disampaikan oleh lembaga keuangan syariah kepada wakif dan nazhir sebagai bukti penyerahan harta benda wakaf

3 Pasal 30: Lembaga Keuangan Syariah (LKS) atas nama nazhir mendaftarkan harta benda wakaf berupa uang kepada Menteri selambat-lambatnya 7 
(tujuh) hari kerja sejak diterbitkannya Sertifikat Wakaf Uang (SWU).

4 Pasal 31: ketentuan lebih lanjut mengenai wakaf benda bergerak berupa uang sebagaimana dimaksud dalam Pasal 28, Pasal 29, dan Pasal 30 diatur dengan Peraturan Pemerintah.

Kemudian dalam peraturan pemerintah disebutkan bahwa wakaf uang yang dapat diwakafkan adalah mata uang rupiah dan apabila berbentuk mata uang asing maka harus dikonvensi terlebih dahulu kedalam rupiah.

Dari Undang-Undang dan peraturan pemerintah tersebut kita bisa tahu bahwa wakaf uang hanya bisa dilakukan dengan mata uang rupiah dan dilaksanakan pada lembaga keuangan syariah yang telah ditunjuk oleh menteri, sampai dengan 31 Desember 2015, Menteri Agama sudah menetapkan 15 bank sebagai penerima setoran wakaf uang, yang disebut LKSPWU. Bank-bank itu adalah sebagai berikut: 1. Bank Muamalat Indonesia 2. Bank Syariah Mandiri 3. Bank BNI Syariah 4. Bank Mega Syariah 5. Bank DKI Syariah 6. Bank BTN Syariah 7. Bank Syariah Bukopin 8. BPD Jogya Syariah 9. BPD Kalbar Syariah 10. BPD Jateng Syariah 11. BPD Kepri Riau Syariah 12. BPD Jatim Syariah 13. BPD Sumut Syariah 14. Bank CIMB Niaga Syariah 15. Panin Bank Syariah.

Pada bank-bank inilah wakaf uang ditunaikan, lebih jelas lagi dalam Peraturan Pemerintah Nomor 42 tahun 2006 disebutkan pada pasal 22 ayat 3-5 dan juga pasal 23: wakif yang akan mewakafkan uangnya diwajibkan untuk hadir di LKS -PWU untuk menyatakan kehendak wakaf uangnya, menjelaskan kepemilikan dan asal-usul uang yang akan diwakafkan, menyetorkan secara tunai sejumlah uang ke LKS- PWU, mengisi formulir pernyataan kehendak wakif yang berfungsi sebagai AIW.

Apabila wakif tidak dapat hadir maka wakif dapat menunjuk wakil atau kuasanya. Wakif dapat menyatakan ikrar wakaf benda bergerak berupa uang kepada nazhir dihadapan PPAIW yang selanjutnya nazhir menyerahkan AIW tersebut kepada LKS-PWU. Wakif dapat mewakafkan benda bergerak berupa uang melalui LKS yang ditunjuk oleh Menteri sebagai Lembaga Keuangan Syariah Penerima Wakaf Uang (LKS-PWU).

Tugas dari LKS-PWU disebutkan dalam pasal 25 Peraturan Pemerintah Nomor 42 Tahun 2006 adalah:

a) Mengumumkan kepada publik atas keberadaannya sebagai LKS PWU;

b) Menyediakan blangko sertifikat wakaf uang;

c) Menerima secara tunai wakaf uang dari wakif atas nama nazhir;

d) Menempatkan uang wakaf ke dalam rekening titipan (wadi'ah) atas nama nazhir yang ditunjuk wakif.

e) Menerima pernyataan kehendak wakif yang dituangkan secara tertulis dalam formulir pernyataan kehendak wakif;

f) Menerbitkan sertifikat wakaf uang serta menyerahkan sertifikat tersebut kepada wakif dan menyerahkan tembusan sertifikat kepada nazhir yang ditunjuk oleh wakif;

g) Mendaftarkan wakaf uang kepada Menteri atas nama nazhir.

Jadi skema praktik wakaf uang dalam Undang-Undang Nomor 41 Tahun 2004 tentang wakaf dan Peraturan Pemerintah Nomor 42 tahun 2006 tentang pelaksanaan Undang-Undang No.41 tahun 2004 tentang wakaf ada dua macam : 


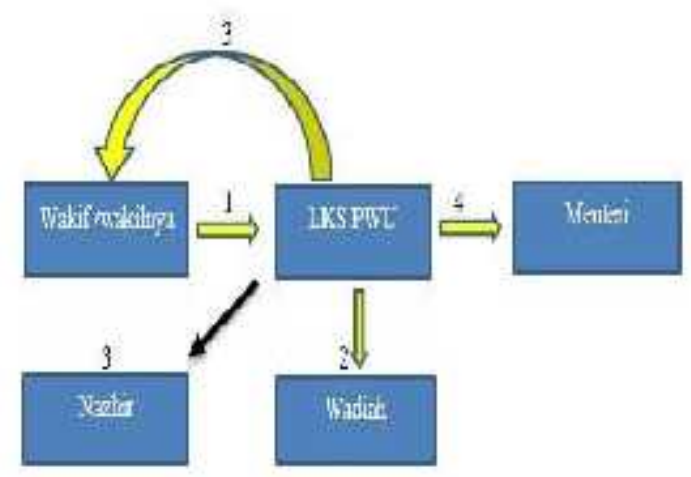

Gambar 1. Skema Praktik Wakaf I

Berdasarkan UU No. 41 tahun 2004

\section{Praktik Pertama:}

1. Wakif atau wakilnya datang ke LKS PWU untuk menyatakan kehendak wakaf uangnya menjelaskan kepemilikan dan asal-usul uang yang akan diwakafkan. Menyetorkan secara tunai sejumlah uang ke LKS-PWU mengisi formulir pernyataan kehendak wakif yang berfungsi sebagai AIW.

2. Menerima secara tunai wakaf uang dari wakif atas nama nazhir menempatkan uang wakaf ke dalam rekening titipan (wadi'ah) atas nama nazhir yang ditunjuk wakif; menerima pernyataan kehendak wakif yang dituangkan secara tertulis dalam formulir pernyataan kehendak wakif.

3. Menerbitkan sertifikat wakaf uang serta menyerahkan sertifikat tersebut kepada wakif dan menyerahkan tembusan sertifikat kepada nazhir yang ditunjuk oleh wakif;

4. Mendaftarkan wakaf uang kepada Menteri atas nama nazhir. Yang kedua sebagaimana skema kedua ini:

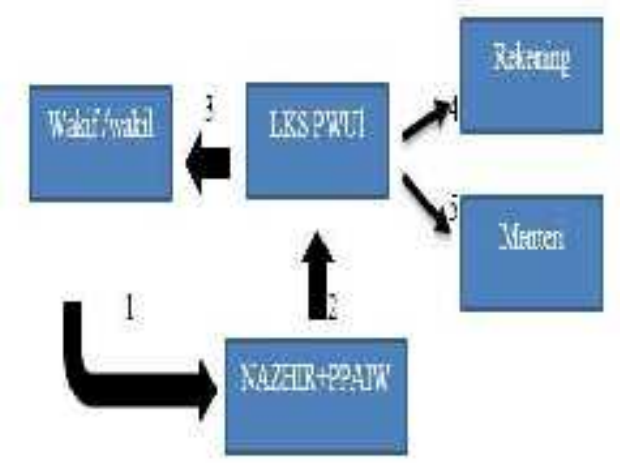

Gambar 2. Skema Praktik Wakaf II Berdasarkan UU No. 41 tahun 2004

Keterangan Skema :

1. Wakif atau wakilnya menyatakan ikrar wakaf benda bergerak berupa uang kepada nazhir di hadapan PPAIW.

2. Nazhir menyerahkan AIW dan uang wakaf tersebut kepada LKS-PWU.

3. LKS-PWU menaruh ke rekening nazhir,

4. Mendaftarkan wakaf uang kepada Menteri atas nama nazhir.

Perbedaan antara dua skema adalah dipernyataan ikrarnya. Untuk yang pertama langsung ke LKS-PWU dan yang kedua di depan nazhir dan PPAIW. Jadi ini yang membedakan antara wakaf benda bergerak berupa uang dengan benda tidak bergerak seperti tanah. Kalau benda bergerak berupa uang pendaftarannya melalui LKS atau notaris (PPAIW) kalau benda tidak bergerak pendaftarannya ke KUA atau juga bisa di Notaris. Selain dengan cara langsung datang dengan setor tunai LKS wakif juga bisa membayarkan wakaf uangnya melalui Electronic Channels yang disediakan LKS-PWU (internet bangking, sms bangking atau ATM, dsb) yang kemudian layanan electronic channels akan mengeluarkan bukti seperti email, surat tertulis, sms sebagai respon transaksi yang dilakukan sekaligus sebagai bukti. Jika nominal wakaf 
mencapai 1 juta rupiah atau lebih, bukti transaksi tersebut diberikan ke LKS PWU untuk mendapatkan sertifakat wakaf uang.

Pengelolaan dan Pendistribusian Wakaf Uang.

Sektor pengelolaan wakaf merupakan bagian yang terpenting dari wakaf, karena fungsi atau manfaat wakaf bisa dirasakan oleh mauquf alaih bila dikelola dengan baik dan profesional dan produktif. Dalam Undang-Undang wakaf dan peraturan pemerintah bagian pengelolaan wakaf juga diatur ada Undang-Undang Nomor 41 Tahun 2002 tentang wakaf diatur pada bab $\mathrm{V}$ yang meliputi pasal 42, 43, 44, 45 dan 46.

1. Nazhir wajib mengelola dan mengembangkan harta benda wakaf sesuai dengan tujuan, fungsi, dan peruntukannya.

2. Pengelolaan dan pengembangan harta benda wakaf oleh nazhir sebagaimana dimaksud dalam Pasal 42 dilaksanakan sesuai dengan prinsip syariah. Pengelolaan dan pengembangan harta benda wakaf sebagaimana dimaksud dilakukan secara produktif. Dalam hal pengelolaan dan pengembangan harta benda wakaf yang dimaksud diperlukan penjamin, maka digunakan lembaga penjamin syariah.

3. Dalam mengelola dan mengembangkan harta benda wakaf, nazhir dilarang melakukan perubahan peruntukan harta benda wakaf kecuali atas dasar izin tertulis dari Badan Wakaf Indonesia. Izin sebagaimana dimaksud hanya dapat diberikan apabila harta benda wakaf ternyata tidak dapat dipergunakan sesuai dengan peruntukan yang dinyatakan dalam ikrar wakaf.
Dalam Peraturan Pemerintah Nomor 42 tahun 2006 pengelolaan wakaf dijelaskan pada pasal 45, 46, 47 dan 48.

1. Nazhir wajib mengelola dan mengembangkan harta benda wakaf sesuai dengan peruntukan yang tercantum dalam AIW. Dalam mengelola dan mengembangkan harta benda wakaf sebagaimana dimaksud pada ayat (1) untuk memajukan kesejahteraan umum, nazhir dapat bekerjasama dengan pihak lain sesuai dengan prinsip syariah.

2. Pengelolaan dan pengembangan harta benda wakaf dari perorangan warga negara asing, organisasi asing dan badan hukum asing yang berskala nasional atau internasional, serta harta benda wakaf terlantar, dapat dilakukan oleh BWI.

3. Dalam hal harta benda wakaf berasal dari luar negeri, wakif harus melengkapi dengan bukti kepemilikan sah harta benda wakaf sesuai dengan ketentuan

Peraturan Perundangundangan, dan nazhir harus melaporkan kepada lembaga terkait perihal adanya perbuatan wakaf.

4. Pengelolaan dan pengembangan harta benda wakaf harus berpedoman pada peraturan BWI. Pengelolaan dan pengembangan atas harta benda wakaf uang hanya dapat dilakukan melalui investasi pada produk-produk LKS dan atau instrumen keuangan syariah. Dalam hal LKS-PWU menerima wakaf uang untuk jangka waktu tertentu, maka nazhir hanya dapat melakukan pengelolaan dan pengembangan harta benda wakaf uang pada LKS-PWU dimaksud. Pengelolaan dan pengembangan atas harta benda wakaf uang yang dilakukan pada bank syariah harus mengikuti program lembaga 
penjamin simpanan sesuai dengan Peraturan Perundangundangan. Pengelolaan dan pengembangan atas harta benda wakaf uang yang dilakukan dalam bentuk investasi diluar bank syariah harus diasuransikan pada asuransi syariah.

Dari Undang-Undang dan peraturan tentang wakaf dapat ditarik kesimpulan bahwa dalam pengelolaan wakaf yang memiliki peran penting adalah nazhir, dimana nazhir dituntut untuk mengelola wakaf sesuai dengan fungsi manfaat dan peruntukannya dengan produktif baik dilakukan sendiri atau dengan bekerjasama dengan pihak lain sesuai dengan prinsip yang tidak bertentangan dengan syariah.

Untuk pengelolaan wakaf uang nazhir hanya boleh mengelola harta benda wakaf uang melalui investasi pada produkproduk LKS atau instrumen keuangan syariah. Apabila nazhir ingin mengelola wakaf uang diluar produk keuangan syariah maka harus di asuransikan pada asuransi syariah. Lebih lanjut dalam peraturan Badan Wakaf Indonesia dijelaskan Sebaran investasi harta dalam bentuk wakaf uang (portofolio wakaf uang) dapat dilakukan dengan ketentuan 60 persen investasi dalam instrumen LKS dan 40 persen diluar LKS. Jadi dari wakaf uang yang terkumpul pada rekening di LKS, nazhir bisa mengelola 60 persen untuk diinvestasikan ke Produk LKS dan 40 persen diluar LKS.

Untuk penyaluran manfaat wakaf uang kepada mauquf alaih disebutkan dalam Undang-Undang wakaf, harta benda wakaf hanya dapat diperuntukan bagi sarana dan kegiatan ibadah, sarana dan kegiatan pendidikan serta kesehatan, bantuan kepada fakir miskin, anak terlantar, yatim piatu, beasiswa, kemajuan dan peningkatan ekonomi umat; dan atau kemajuan kesejahteraan umum lainnya yang tidak bertentangan dengan syariah dan peraturan perundang-undangan. Untuk penyaluran manfaat dari wakaf uang sendiri dijelaskan pada peraturan Badan Wakaf Indonesia. Dimana ada dua macam cara penyaluran manfaat wakaf, pertama secara langsung dan kedua secara tidak langsung.

Penyaluran manfaat hasil pengelolaan dan pengembangan harta benda wakaf secara langsung adalah program pembinaan dan pemberdayaan masyarakat yang secara langsung dikelola oleh nazhir. Program pembinaan dan pemberdayaan masyarakat ini harus memenuhi berapa syarat, diantaranya:
a. Program
pembinaan
dan
pemberdayaan
masyarakat
dijalankan sesuai dengan syariah dan peraturan perundang-undangan.
b. Tepat sasaran.
$\begin{array}{lrr}\text { c. Berdampak pada } & \text { pengurangan } \\ \text { kemiskinan } & \text { dan } & \text { membuka }\end{array}$ lapangan pekerjaan.

d. Program berkesinambungan dan mendorong kemandirian masyarakat.

Beberapa program pembinaan dan pemberdayaan yang disebutkan diantaranya seperti program sosial dan umum berupa pembangunan fasilitas umum antara lain jembatan, jalan mandi cuci kakus umum dan masjid. Program pendidikan berupa pendirian sekolah dengan biaya murah untuk masyarakat tidak mampu dan pelatihan keterampilan. Program kesehatan berupa bantuan pengobatan bagi masyarakat miskin dan penyuluhan ibu hamil dan menyusu. Program ekonomi berupa pembinaan dan bantuan modal usaha mikro, penataan pasar tradisional dan pengembangan usaha pertanian dalam arti luas, Program 
dakwah berupa penyediaan da'i dan mubaligh, bantuan guru, bantuan bagi imam dan marbot masjid.

Penyaluran manfaat hasil pengelolaan dan pengembangan harta benda wakaf secara tidak langsung maksudnya nazhir menyalurkan melalui lembaga lain seperti: lembaga pengelola zakat, baitul mal wa tamwil, lembaga kemanusiaan nasional, lembaga pemberdayaan masyarakat nasional, yayasan atau perkumpulan organisasi kemasyarakatan, lembaga lain baik berskala nasional maupun internasional yang melaksanakan program pembinaan dan pemberdayaan masyarakat sesuai dengan syariah dan peraturan perundang-undangan.

Lembaga-lembaga yang dimaksud itupun harus memenuhi syarat-syarat yang harus dipenuhi, yaitu: memiliki kelengkapan legal formal lembaga, yayasan, perkumpulan atau organisasi kemasyarakatan sesuai peraturan perundang-undangan. Paling kurang telah beroperasi selama 2 (dua) tahun. Memiliki pengurus yang tidak tercela. Menyertakan laporan audit independen dalam 2 (dua) tahun terakhir dan memiliki program yang jelas dan memberikan dampak positif.

Dari penjalasan tentang mekanisme pengelolaan wakaf uang dan penyaluran manfaat wakaf uang baik yang ada pada Undang-Undang wakaf atau Peraturan Pemerintah tentang wakaf dan peraturan Badan Wakaf Indonesia sebagai regulator wakaf di Indonesia bisa digambarkan pada gambar 3.

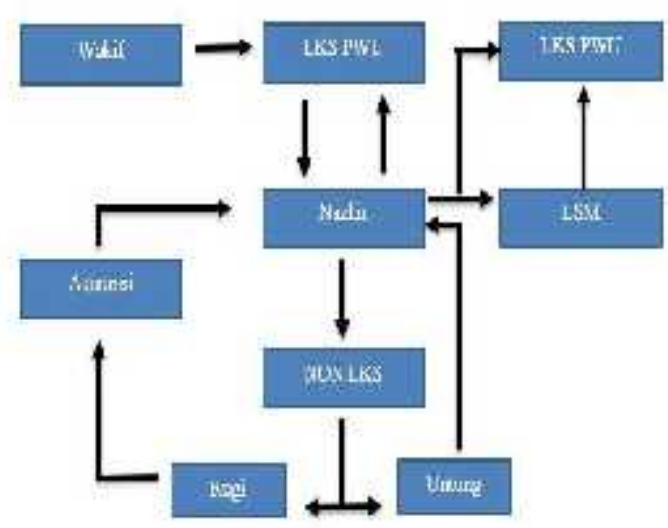

Gambar 3. Mekanisme Pengelolaan Wakaf dan Penyaluran Manfaat Wakaf

\section{Praktik Wakaf Uang Pada Tabung Wakaf Indonesia.}

Penghimpunan harta wakaf uang pada Tabung Wakaf Indonesia dimulai sebelum Dompet Dhuafa Republika mendirikan Tabung Wakaf Indonesia yaitu sejak tahun 2001. Pada tahun pertama itu Dompet Dhuafa mampu menghimpun dana wakaf uang sebesar Rp 86.968.000,00. Penghimpunan dana wakaf uang ini meningkat pada tahun 2002, sebesar Rp 822.451.600,00. Peningkatan ini mungkin dipengaruhi oleh fatwa MUI tentang wakaf uang yang dikeluarkan pada tanggal 11 Mei 2002. Dari tahun ketahun pendapatan wakaf pada Tabung Wakaf Indonesia terus meningkat.

Penghimpunan dana wakaf uang Dompet Dhuafa sendiri sebelum adanya Undang-Undang wakaf No.41 tahun 2004. Dan jauh sebelum didirikannya BWI sebagai lembaga yang mengatur dan mengawasi wakaf berskala nasional yang berdiri pada tahun 2007.

Cara berwakaf uang pada Tabung Wakaf Indonesia ada dua cara, pertama dengan cara setor tunai atau transfer melalui bank-bank Syariah yang sudah mendapat SK dari Menteri menjadi LKSPWU. Bank yang menjadi mitra TWI ada 
dua Bank Syariah Mandiri (BSM) dan Bank BNI Syariah. Wakif dapat mewakafkan uangnya dengan langsung datang kedua bank tersebut dengan setor tunai melalui rekening TWI (an. Dompet Dhuafa) 700.049.3133 untuk BSM, dan 009.1538995. untuk BNI Syariah. Setelah setor atau transfer uang sebagai wakaf, wakif mengkonfirmasi donasi wakaf melalui sms center TWI: 0812.8036 .0688 dan selanjutnya akan dikonfirmasi oleh bagian funding TWI. Untuk ditanya berapa wakaf jumlah wakaf yang tunaikan dan diperuntukkan untuk apa. Setelah itu apabila wakaf uang yang disetorkan 1 juta atau lebih maka wakif akan mendapat sertifikat wakaf dari TWI dan dikirimkan kealamat wakif.

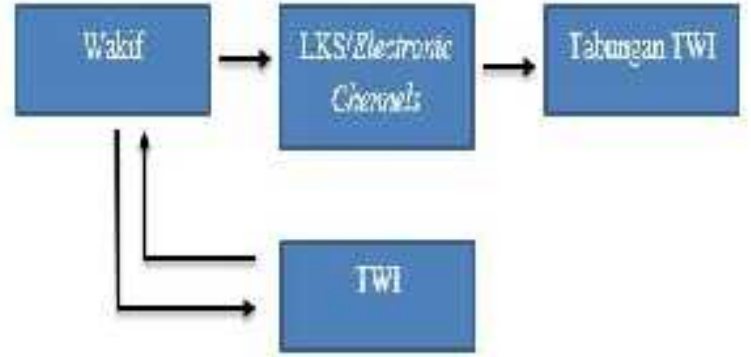

Gambar 4. Mekanisme Penyerahan Dana Wakaf

Cara yang kedua adalah dengan datang langsung kekantor TWI atau kantor-kantor cabang Dompet Dhuafa diberbagai kota. Kemudian mengisi formulir ikrar wakaf dan akan mendapat sertifikat wakaf apabila wakaf yang ditunaikan mencapai 1 juta atau lebih.

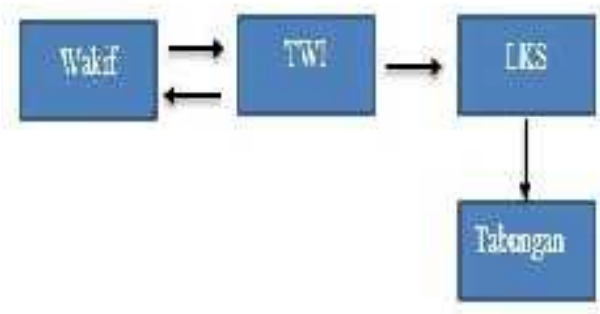

Gambar 5. Mekanisme Cara Berwakaf di TWI
Dari penjelasan tentang cara berwakaf uang di Tabung wakaf Indonesia ada sedikit perbedaan dengan apa yang ada di Undang-Undang Nomor 41 tahun 2004 tentang wakaf dan Peraturan Pemerintah No.42 tahun 2006 tentang pelaksanaan Undang-Undang Nomor 41 tahun 2004 tentang wakaf, diantaranya adalah:

1) Pencetakan sertifikat wakaf uang, didalam undang-undang wakaf yang mengeluarkan sertifakat wakaf adalah LKS PWU, sedangkan pada praktik yang ada di TWI. Pihak TWI-lah yang mengeluarkan sertifikat.

2) Pada praktik wakaf yang kedua TWI hanya menyetorkan uang wakaf dari wakif ke LKS untuk ditaruh di rekening Dompet Dhuafa tanpa menyerahkan akta ikrar wakaf.

Untuk pelaporan penerimaan wakaf uang TWI melaporkan setiap tahun ke Badan Wakaf Indonesia. Dalam menghimpun wakaf uang TWI menerapkan skema bank syariah hanya sebagai kasir tabung wakaf yang dihimpun pada rekening Dompet Dhuafa. Dana wakaf yang dihimpun, dikelola langsung oleh Tabung Wakaf Indonesia. Skema UndangUndang LKS PWU adalah sebagai kustodi yaitu sebagai penerima dan pencatat dan melaporkan wakaf uang sebagaimana dijelaskan oleh Cholil Nafis mantan sekjen BWI ketika ditemui dikantornya. Mengenai beberapa ketidak sesuaian praktik wakaf uang ini ada beberapa alasan yang menjadi dasar:

1. Kerjasama antara TWI Dompet Dhuafa dan LKS hanya sebatas nasabah biasa bukan antara nazhir dengan LKS PWU, jadi LKS tidak memiliki keharusan mencetak sertifikat.

2. Rumitnya administrasi untuk mendapat rekening nazhir wakaf 
sehingga TWI tidak memiliki rekining sendiri tetapi masih menggunakan rekening Dompet Dhuafa.

3. LKS PWU yang sudah mendapat SK dari menteri tidak menyediakan layanan setor wakaf tunai pada setiap cabang atau capem. Menurut Cholil Nafis dikarenakan untuk mensosialisasikan dan menerapkan wakaf uang pihak bank memerlukan beberapa biaya seperti SDM yang mengerti wakaf, mencetak formulir wakaf, mencetak sertifikat wakaf, sedangkan produk wakaf uang di Indonesia masih sedikit, tentu ini akan mengakibatkan bertambahnya biaya pengeluaran yang dikeluarkan oleh bank sedangkan pendapatan dari wakaf uang sangat minim ini karena minimnya pengetahuan masyarakat terhadap wakaf uang serta kurangnya sosialisasi wakaf uang oleh pihak BWI atau pemerintah.

4. Praktik wakaf uang pada TWI Dompet Dhuafa sudah berjalan sejak sebelum disahkannya Undang-Undang wakaf sehingga memerlukan waktu untuk beradaptasi dengan Undang-Undang.

Perbedaan antara praktik yang terdapat di Undang-Undang dengan praktik yang ada di TWI sebagaimana gambar ini:

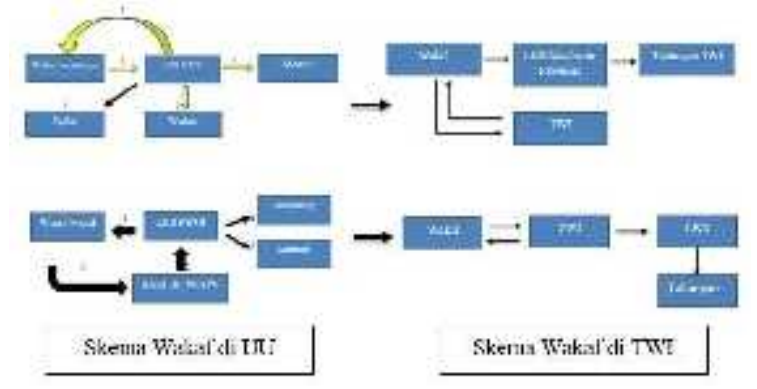

Gambar 6. Perbedaan Praktik Wakaf di TWI dan Undang-Undang

\section{Pengelolaan wakaf uang Pada Tabung Wakaf Indonesia.}

Dalam pengelolaan harta wakaf uang TWI selaku nazhir melakukan pengelolaan dan pengembangan harta benda wakaf yang dihimpunnya sesuai dengan tujuan, fungsi dan peruntukannya dengan prinsip-prinsip yang tidak keluar dari syariah syariah. Harta benda wakaf yang diterima oleh TWI dikelola secara produktif yang dilakukan berdasarkan tiga pendekatan, yaitu pendekatan produktif, nonproduktif, dan terpadu (gabungan pendekatan produktif dan non produktif pada satu objek wakaf).

Pendekatan produktif, TWI mengelola harta wakaf untuk hal-hal yang sifatnya produktif dan menghasilkan keuntungan dan keuntungan ini akan dimanfaatkan untuk kemaslahatan masyarakat banyak dengan tetap mempertahankan nilai pokok dari harta wakaf. Dalam hal ini TWI mengalokasikan dana wakafnya untuk:

Wakaf peternakan, TWI menginvetasikan dana wakaf untuk peternakan bekerjasama dengan jejaring Dompet Dhuafa lain, yakni Kampoeng Ternak. Lembaga ini telah sukses memberdayakan peternak dan memiliki mitra diberbagai kota di Indonesia. Kampoeng Ternak juga aktif dalam program pendistribusian hewan qurban, serta melakukan serangkaian riset, diklat dan pendampingan sektor peternakan.

Wakaf pertanian TWI bekerja di sektor pertanian bermitra, antara lain, dengan Lembaga Pertanian Sehat (LPS), jejaring Dompet Dhuafa lain, yang bergiat dalam pertanian sehat. LPS juga bergiat menyiapkan sarana produksi pertanian dari bahan organik.

Wakaf perkebunan Saat ini TWI menjalankan program usaha perkebunan 
di dua daerah. Pertama, di, Kabupaten Lahat, Sumatra Selatan, untuk perkebunan karet, bersama-sama masyarakat setempat. Kedua, di Kabupaten Banggai, Sulawesi Tengah, untuk perkebunan cokelat dan kelapa. Hasil dari perkebunan cokelat dan kelapa ini digunakan untuk mendanai satu-satunya SMU yang ada di sana yaitu SMU Mansamat. Dan juga menjalankan perkebunan sengon di Bojong Koneng Sentul Bogor, dan Jonggol, serta perkebunan jabon disukabumi.

Wakaf usaha perdagangan dalam usaha perdagangan TWI akan bermitra dengan para pedagang, baik kecil maupun menengah, mengelola kemitraan dagang dengan menerapkan kontrak qirad. Qirad merupakan sejenis modal ventura yang diberikan kepada mitra terpilih sebagai pinjaman tanpa bunga, tanpa agunan, dan tanpa syarat ekuitas. Ketentuan bagi hasil hanya berlaku bagi usaha kemitraan dagang yang sukses dan memberikan surplus. Bila usaha gagal dan merugi, yang bukan disebabkan oleh kecerobohan mitra, maka risiko sepenuhnya ditanggung oleh TWI sebagai penyandang dana.

Wakaf sarana niaga dengan wakaf tunai atau non tunai TWI akan membangun atau mengadakan berbagai sarana niaga, seperti pertokoan, permesinan, kendaraan, dan sebagainya, untuk disewakan kepada pihak ketiga. Hasil penyewaan sarana niaga ini akan dijariahkan untuk beragam kegiatan sosial sesuai dengan permintaan wakifnya.

TWI-DD juga sedang membangun rumah sewa di Ciledug, ada juga DD futsal yang berada di Ciputat aset wakaf berbentuk sarana olahraga. Untuk pendekatan non produktif, TWI mengelola harta wakaf hal-hal yang sifatnya tidak menghasilkan keuntungan (non produktif). Menurut Mahmud dari bagian direktorat wakaf Dompet Dhuafa saat ditanya tentang jenis wakaf ini merupakan wakaf sosial yang non-profit atau nonbusiness, yang mana donasi yang diperoleh akan dipergunakan untuk membangun, mengakuisisi atau merenovasi, aset wakaf yang non-profit, seperti pembangunan Layanan Kesehatan Cuma-Cuma (LKC) bagi para dhuafa dan pendirian sekolah gratis untuk kaum dhuafa seperti Smart Ekselensia. Dimana biaya oprasionalnya dicarikan dari dana lain seperti zakat, infak dan sedekah, dan juga untuk pembangunan wisma mualaf.

Pada tahun ini TWI memiliki mega projek yang masih berjalan yaitu pembangunan masjid Al-Madinah di kawasan zona madina yang terletak di kawasan Jl. Raya Parung KM No.42, Jampang, Kemang, Bogor, Jawa Barat, dan wakaf rumah sakit AK Medika Sribhawono di Lampung. Menurut keterangan dari pihak direktorat wakaf Dompet Dhuafa jenis wakaf ini bukan jenis wakaf uang melainkan wakaf melalui uang yang mana uang yang diwakafkan digunakan untuk pembangunan program yang dijalankan oleh TWI Dompet Dhuafa.

Sedangkan pendekatan terpadu yaitu program penyaluran wakaf untuk sarana dan prasarana pelayanan umat dikombinasikan dengan program wakaf dalam bentuk sarana niaga, properti, perkebunan, perdagangan, pertanian, dan lain-lain. Surplusnya disalurkan untuk kaum dhuafa dan atau untuk oprasional institusi pelayanan umat dalam satu area program, seperti Rumah Sakit Terpadu di kawasan zona madinah di desa Jampang, Kemang Kabupaten Bogor.

Investasi yang dilakukan oleh TWI Dompet Dhuafa ada dua macam, pertama wakaf uang dan kedua wakaf melalui uang. Wakaf uang yang terkumpul digunakan 
untuk diinvestasikan secara langsung (direct investment) ke sektor riil secara keseluruhan, tidak di investasikan ke produk keuangan syariah, sesuai dengan pasal 48 ayat 2 Peraturan Pemerintah RI Nomor 42 Tahun 2006 tentang pelaksanaan Undang-Undang Nomor 41 Tahun 2004 Tentang Wakaf. Menurut pihak Dompet Dhuafa aturan yang ada di undangundang membatasi ruang gerak nazhir dalam pengelolaan wakaf uang apalagi jika mengikuti peraturan Badan Wakaf Indonesia yang mengharuskan Sebaran investasi harta dalam bentuk wakaf uang (portofolio wakaf uang) dapat dilakukan dengan ketentuan 60 persen investasi dalam instrumen LKS dan 40 persen diluar LKS. Manfaat dari pengelolaan langsung kesektor riil dianggap lebih tepat karena dapat dirasakan oleh para mauquf alaih daripada diinvestasikan ke produk LKS.

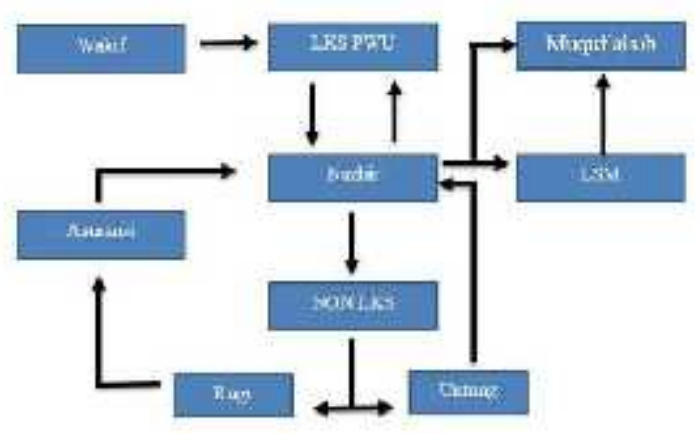

Melihat apa yang sudah dilakukan oleh TWI dalam mengelola wakaf uang sudah sesuai dengan tujuan dan fungsi harta benda wakaf karena dikelola dengan produktif yang manfaatnya dapat dirasakan oleh masyarakat umum maka ketidak sesuaian yang ada, tentang investasi harta benda wakaf uang yang langsung diinvestasikan ke sektor riil dapat terttupi, bahkan bisa jadi percontohan apa yang dilakukan oleh Tabung Wakaf Indonesia untuk nazhir lain dalam pengelolaan wakaf uang. Dan yang paling penting lagi adalah pengelolaan yang dilakukan oleh tabung wakaf Indonesia tidak melanggar aturan-aturan syariah.

\section{Kesimpulan dan Implikasi}

Hasil yang disimpulkan adalah sebagai berikut:

1. Praktik wakaf uang yang ada di Tabung Wakaf Indonesia ada dua cara pertama melalui setor tunai atau transfer di bank yang sudah memiliki SK dari Menteri dalam hal ini Bank Syariah Mandiri dan BNI Syariah dan kedua dengan datang langsung ke kantor Dompet Dhuafa baik pusat atau cabang-cabang disetiap kota, dan juga bisa digerai-gerai Dompet Dhuafa yang berada di pusat-pusat perbelanjaan. Dan akan mendapat sertifikat wakaf uang apabila jumlah uang yang diwakafkan lebih dari 1 juta.

2. Dalam pengelolaan wakaf uang, Tabung Wakaf Indonesia menggunakan pendekatan produktif, non produktif dan terpadu.

3. Untuk kegiatan produktif yang menghasilkan profit atau keuntungan, TWI memilih untuk menginvestasikan secara langsung (direct investment) kesektor riil seperti investasi peternakan, pertanian, perkebunan sengon dan jabon, sarana olahraga futsal, sarana niaga, sewa ruko sewa rumah. Untuk pendekatan non produktif TWI menginvestasikan untuk pembangunan berbagai asset nonprofit seperti pendirian sekolah Smart Exselensia, Layanan Kesehatan Cuma-Cuma, pembangunan masjid AlMadinah dan yang terbaru adalah pembangunan rumah sakit 
Sribhawono di lampung, sebenarnya ini bukanlah wakaf uang akan tetapi wakaf melaui uang, yaitu wakaf sejumlah uang untuk dijadikan asset wakaf seperti masjid dan lainnya. Dan pendekatan terpadu adalah gabungan antara produktif dan non produktif .

4. Pendistribusian manfaat atau surplus wakaf di TWI diberikan melalui program-program yang dimiliki Dompet Dhuafa seperti untuk pendidikan gratis, kesehatan gratis dan pemberdayaan ekonomi. Mengenai Praktik dan pengelolaan wakaf uang di TWI ada beberapa yang tidak sesuai dengan peraturan perudang-undangan seperti dalam setor wakaf uang TWI hanya menjadikan LKS-PWU sebagai kasir Dompet Dhuafa dan menerbitkan sertifikat sendiri padahal dalam Undang-Undang

5. Tugas LKS-PWU adalah mengumumkan kepada publik atas keberadaannya sebagai LKS-PWU, menyediakan blangko Sertifikat Wakaf Uang, menerima secara tunai wakaf uang dari wakif atas nama nazhir, menempatkan uang wakaf kedalam rekening titipan (wadi'ah) atas nama nazhir yang ditunjuk wakif; menerima pernyataan kehendak wakif yang dituangkan secara tertulis dalam formulir pernyataan kehendak wakif; menerbitkan sertifikat wakaf uang serta menyerahkan sertifikat tersebut kepada wakif dan menyerahkan tembusan sertifikat kepada nazhir yang ditunjuk oleh wakif; dan mendaftarkan wakaf uang kepada Menteri atas nama nazhir. Untuk pembayaran wakaf uang langsung dikantor TWI atau Dompet Dhuafa pun tanpa ada petugas PPAIW dari bank atau notaris. Ini karena beberapa alasan pertama tidak semua kantor cabang LKS- PWU menyediakan formulir wakaf uang. Pendaftaran rekening wakaf di LKS PWU sangat rumit sehingga sampai saat ini TWI tidak memiliki rekening sendiri tetapi masih menggunakan rekening Dompet Dhuafa sebagai induk lembaga. Penghimpunan dana wakaf uang di TWI Dompet Dhuafa sudah berjalan sebelum disahkannya Undang-Undang wakaf.

6. Untuk pengelolaan wakaf uang di TWI juga masih ada beberapa yang tidak sesuai dengan Undang-Undang wakaf dan peraturan tentang wakaf diantaranya: TWI tidak menginvestasikan ke produk LKS tetapi lebih memilih diinvestasikan secara langsung (direct investment) ke sektor riil yang produktif. Padahal dalam peraturan wakaf persentase pengelolaan wakaf di LKS 60 persen dan 40 persen diluar LKS. Untuk penyaluran hasil wakaf produktifnya TWI menyerahkan ke Dompet Dhuafa untuk kepentingan program Dompet Dhuafa seperti pendidikan gratis, layanan kesehatan gratis, dan pemberdayaan ekonomi ini sudah sesuai dengan apa yang ada dalam Undang-Undang.

\section{DAFTAR PUSTAKA}

Ad-Dimasyqi, I. A.-K.-S.-Q. (n.d.). Tafsir alQuran al-Adzim. Maktabah Syamilah.

Al-Amadi, A. S. (1997). Risalah Fi Jawazi Waqf Nuqud. Bairut, Lebanon: Dar Ibn Hazm.

Al-Anshari, z. b. (n.d.). Asna al-Mathalib Fi Syarh Raudhat at-Thalib. Maktabah Syamilah . 
Al-Husaini, T. A. (1994). Kifayatul Ahyar Fi Hill ghayatil Ikhtishar. Bairut: Dar alFikr.

Al-Jamal, A. S. (1994). Hasyiat al-Jamal ala Syarh al-Minhaj. Bairut: Dar al-Fikr

Al-jaml, a.-s. S. (n.d.). Hasyiat al-Jamal ala al-Minhaj li Syaikh Islam Zakaria alAnsyary. Bairut : Dar al-Fikr .

Al-Khatib, M. S. (1415). al-Iqna' fi hilli alfadzi abi syuja'. bairut: Dar al-Fikr.

Al-Maiman, D. N. (2004). Nawazil AlWaqfiyah . Saudi Arabia: Dar Ibn AlJauzi. al-Sa'rani, I. A. (2009). Al-Mizan Al-Kubra Al-Sa'raniyyah. Bairut, Lebanon: Dar

Al-Kotob Al-Ilmiyah.

As-Syathiri, A. b. (2011). Al-Yaqutu an-Nafis fii Madzhabi Ibn idris. Bairut: Dar

Al-Minhaj.

At-Thabary, A. J. (n.d.). Tafsir At-Thabari : Jaamiul Bayan an Ta'wilil Qur'an. In

Tafsir At-Thabari : Jaamiul Bayan an

Ta'wilil Qur'an (pp. Jilid 6 hal 588-

589). Maktabah Syamilah.

Dr. Rozalinda, M. (2015). Manajemen Wakaf Produktif. Jakarta: Rajawali Pers. Fanani, M. (2011, Mei). Pengelolaan Wakaf Tunai. walisongo, 19, 180.

Furqon, A. (2011, Mei 1). Analisi Praktek Perwakafan Uang Pada Lembaga

Keuangan Syariah. Walisongo, 158.

Hasan, A. (1999). Al-Auraq al-naqdiyah fi alIqtishad al-Islami. Damaskus: Dar alFikr.

Hasan, A. (2005). Al-Auraq al-naqdiyah fi aliqtishad al-Islami.

Ibrahim, A. a.-G. (2010). Al-Lubab fi Syarh al-Kitab. Bairut: Maktabah Syamilah

Ibrahim, D. M. (2009). Waqf An-Nuqud (Wakaf Uang) Dalam Presepektif

Hukum Islam. Al-Awqaf, 3.

Kementrian Agama RI Direktorat Jendral Bimbingan Masyarakat Islam Direktorat Pemberdayaan Wakaf. (2010). Pedoman Pengelolaan Wakaf Tunai (VII ed.). Jakarta: Kementrian Agama RI .

Laporan tahunan Dompet Dhuafa. (2013). Gelombang Ekonomi Zakat. Ciputat: Dompet Dhuafa.
MUI, T. P. (2015). Kumpulan Fatwa MUI Sejak 1975. Jakarta: ERLANGGA. Nafis, M. C. (2011). Aplikasi Wakaf Uang di Indonesia. Al-Awqaf , 41.

Novilianto, R. D. (2013). Politik Kebijakan wakaf: Proses Perumusan UU No 41 Tahun 2004 Tentang Wakaf. Al-Awqaf, 85.

rof.Dr.H.M.Burhan Bungin, S. M. (2007). Penelitian Kualitatif (Komunikasi, Ekonomi, kebijakan Publik, Dan Ilmu Sosial Lainnya. Jakarta: Kencana Prenada Media Group.

Soekanto, S. (1998). Pengantar Penelitian Hukum. Jakarta : UI Pres. Soeratno. (1995). Metodologi Peneltian. Jakarta: Prenada Media Grup. Sugiyono. (2009). Metode Penelitian Bisnis. Bandung: Alfabeta.

Sugiyono, P. D. (2008). Metode Penelitian Kuantitatif Kualitatif dan $R \& D$.

Alfabeta.

Tabung Wakaf Indonesia . (2016, September ). http://tabungwakaf.com. Retrieved from http://tabungwakaf.com

Tim Laskar Pelangi. (2013). Metodologi Fiqih Muamalah Diskursus Metodologis

Interaksi Sosial-Ekonomi. Kediri: Lirboyo Press. 